2015

\title{
A Report on the Flawed Proposals for Investor- State Dispute Settlement (ISDS) in TTIP and CETA
}

Gus Van Harten

Osgoode Hall Law School of York University, gvanharten@osgoode.yorku.ca

Follow this and additional works at: http:// digitalcommons.osgoode.yorku.ca/olsrps

\section{Recommended Citation}

Van Harten, Gus, "A Report on the Flawed Proposals for Investor-State Dispute Settlement (ISDS) in TTIP and CETA" (2015).

Osgoode Legal Studies Research Paper Series. 90.

http://digitalcommons.osgoode.yorku.ca/olsrps/90 


\title{
OSGOODE HALL LAW SCHOOL LEGAL STUDIES RESEARCH PAPER SERIES
}

Research Paper No. 16

Vol. 11/ Issue. 04/ (2015)

\section{A report on the flawed proposals for investor- state dispute settlement (ISDS) in TTIP and CETA}

\author{
Gus Van Harten
}

Editors:

Editor-in-Chief: Carys J. Craig (Associate Dean of Research \& Institutional Relations and Associate Professor, Osgoode Hall Law School, York University, Toronto)

Production Editor: James Singh (Osgoode Hall Law School, York University, Toronto) 
Osgoode Legal Studies Research Paper No. 16

Vol. 11/ Issue. 04/ (2015)

\title{
A report on the flawed proposals for investor-state dispute settlement (ISDS) in TTIP and CETA
}

\author{
Gus Van Harten
}

\begin{abstract}
:

\section{Keywords:}

Investment, arbitration, ISDS, TTIP, CETA

\section{Author(s):}

Gus Van Harten

Osgoode Hall Law School

York University, Toronto

E: gvanharten@osgoode.yorku.ca
\end{abstract}

This discussion paper elaborates on five serious flaws with proposals for investor-state dispute settlement (ISDS) in proposed Europe-United States and Europe-Canada trade deals known by the acronyms TTIP and CETA. The issues elaborated in the paper are: the unjustified replacement of judges with arbitrators, the lack of institutional safeguards of independence and fairness in ISDS, the privileging of foreign investors over other actors, the risk to European standards of regulation, and the fact that TTIP (and to a lesser extent CETA) would expand the scope of ISDS massively. The paper is written from a European perspective, considering that most European countries and the European Union have not agreed to ISDS in any past treaty with the U.S. or Canada and thus would assume muchexpanded risks and constraints associated with ISDS due to TTIP or CETA. 


\title{
A report on the flawed proposals for investor-state dispute settlement (ISDS) in TTIP and CETA
}

\author{
Gus Van Harten ${ }^{1}$ \\ gvanharten@osgoode.yorku.ca
}

April 10, 2015

There are five serious flaws with ISDS as proposed in the Europe-U.S. Transatlantic Trade and Investment Partnership (TTIP) and in the Canada-EU Comprehensive Economic and Trade Agreement (CETA).

\section{The unjustified replacement of judges with arbitrators}

ISDS shifts powers of domestic and international courts to for-profit arbitrators whose proposed powers and procedures do not satisfy basic standards of judicial independence and fair process.

The powers shifted to arbitrators are among the highest that any adjudicator can exercise. They involve the final determination of the legal boundaries of sovereign authority, as exercised by any legislative, executive, or judicial body, based on broad standards of foreign investor protection. They can lead to the assignment of potentially vast amounts of public funds to private actors, usually large companies. They are backed by an international enforcement system that is more powerful than that of domestic or international courts. They are subject to very limited judicial review or no judicial review at all, depending on the arbitration rules under which the foreign investor chooses to bring its claim.

No serious justification based on any sort of systematic evidence has been offered for the replacement of judges with this arbitration process. To justify the shift, proponents of ISDS sometimes point to one or a few select cases in which a foreign investor was mistreated at the hands of a court. Such cases will no doubt exist in any adjudicative system, including ISDS itself. Yet they do not offer a sound basis for conclusions about courts' reliability or fairness. Moreover,

1 Tenured faculty member/ associated professor, Osgoode Hall Law School of York University, Toronto; LLB, MES, PhD in Law: "The Emerging System of International Investment Arbitration" (London School of Economics, 2006). Open access to research publications: http://ssrn.com/author=638855.

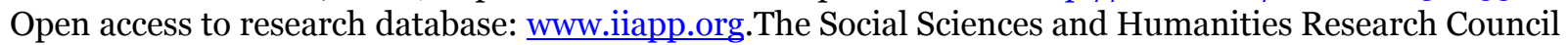
of Canada and the Law Commission of Ontario provided financial support for research discussed in this paper. 
even in the cases they have selectively identified as evidence of the need for ISDS, proponents including the European Commission have made misleading statements about the role and reliability of courts, as opposed to ISDS, for foreign investors.

For example, in defending the proposed ISDS mechanism in the Canada-EU Comprehensive Economic and Trade Agreement (CETA), the European Commission reported inaccurately to European Parliamentarians that the Dunsmuir decision of the Supreme Court of Canada on judicial review in Canada "does not allow an examination of the merits of an administrative act, but only one of process". This is totally wrong, as I outline in Appendix 1 of this report and had the evident unfortunate effect of misleading Parliamentarians about the adequacy of Canadian courts and law for protecting foreign investors.

ISDS proponents also often point to the NAFTA case of Loewen to claim there is a need for ISDS to protect European investors in the U.S. Yet, they do not report that Loewen was actually lost by the Canadian investor who brought the claim due to an exceptionally U.S.-friendly ruling by the NAFTA ISDS tribunal and that, after the Loewen decision was issued, a member of the NAFTA tribunal spoke publicly about pressure that was brought to bear on him by U.S. Justice Department officials at the time of his appointment to the tribunal, which encouraged him to ensure that the U.S. did not lose the case. ${ }^{2}$ I elaborate on this example also in Appendix 1.

It is important that ISDS be rejected in the TTIP in the absence of a serious case for providing foreign investors with special privileges, procedural or substantive, compared to all other actors in the economy and society. The decision to give a special status to any actor, here in practice among the largest companies in the world, demands clear evidence that doing so will deliver a public benefit to outweigh the disadvantages to other actors and the costs to the public.

\section{The lack of institutional safeguards of independence and fairness in ISDS}

The ISDS arbitration process does not satisfy requirements of fair process and of judicial independence and impartiality. This is because:

\footnotetext{
2 D. Schneiderman, "Judicial Politics and International Investment Arbitration: Seeking an Explanation for Conflicting Outcomes” (2010) 30 Northwestern Journal of International and Business Law 383 at $404-5$.
} 
- There is a basic lack of procedural fairness for all parties except the foreign investor and the responding governmental body (e.g. a national government or the European Commission). Simply, ISDS does not afford rights of standing in the process for all parties whose rights or interests are affected. Such other parties could include another level of government, a domestic investor, a community, or a private individual who may have a legal, economic, or reputational interest in the outcome of the adjudication. Instead, other affected parties will be able only to file submissions with the tribunal, at the tribunal's discretion, in quite limited circumstances. In a fair process, anyone whose rights or interests were affected significantly should be able to participate fully by accessing the record of the proceedings, filing evidence, making factual and legal arguments alongside the other affected parties, and so on. ISDS does not allow this, except for the foreign investor.

- ISDS uses a for-profit business of arbitration in which conventional safeguards of judicial independence are absent. For example, ISDS does not provide for secure judicial tenure of its adjudicators; it fails to set salaries that do not depend on whether a case goes ahead and how long it takes to resolve; it does not prohibit parallel legal work by the arbitrators, thus giving rise to unverifiable conflicts of interest in the system; and it does not use an objective method of case assignment. All of this flies in the face of well-established norms of fair process and checks against conflicts of interest.

- Unlike other forms of arbitration, ISDS is a uniquely non-reciprocal, involving private claims for compensation against the state in its sovereign as opposed to its commercial role. As a result, only one side - foreign investors - can initiate the claims that generate the fees for arbitrators and the associated legal industry. This creates an impression of inappropriate economic incentives for arbitrators to favour foreign investors, as prospective claimants, across the system.

- An executive official has the power to choose who will decide any particular case, after the official is aware who has sued whom and for what reason. Under the Canada-EU CETA, which is a model for the proposed ISDS procedure in the TTIP, this key political power over ISDS cases is given to the Secretary-General of the World Bank's International Center for Settlement of Investment Disputes (ICSID) and, in the case of ICSID annulment proceedings, to the President of the World Bank. Both officials operate in a political orbit that is closer to the U.S. Administration than to any other government. With this in mind, 
the TTIP looks like an effort to re-direct disputes to a friendlier forum for some foreign investors and governments.

- There is no judicial supervision of potential legal and factual errors by ISDS arbitrators. If the foreign investor chooses to sue under the ICSID Rules, the lack of judicial supervision extends even to jurisdictional errors and gross procedural improprieties on the part of arbitrators.

- The European Commission's proposed "roster" of ISDS arbitrators is very weak as a means to support judicial independence. Roster members are not judges in the manner of a court. The roster applies only for the presiding and state-appointment members of the roster, leaving foreign investors with control or influence over half the tribunal's membership in a process where private parties cannot even have standing. Executive officials will also continue to choose who is appointed from the roster and to ICSID annulment panels. Executive officials may appoint arbitrators from beyond the roster if the states parties do not agree on roster membership. For 20 years, this last loophole has prevented the use of a similar roster in NAFTA's investment chapter. The absence of an objective method of case assignment is a serious challenge to judicial independence.

- Due to the high-level of secrecy in some ISDS cases under existing treaties, conflicts of interest in the arbitration process cannot be policed effectively by the parties or anyone else. The arbitrators are not barred from side work as lawyers during and after their term on the roster. As a result, arbitrators may be incented financially to rule on a legal issue in one case in a way that benefits paying clients in another. Yet, due to the existence of ISDS cases that are completely secret, no one can verify independently an arbitrator's disclosure of situations of potential conflict of interest due to side work as a lawyer.

- The European Commission's ISDS model leaves it to the ISDS arbitrators in any particular case to weed out frivolous claims by foreign investors. However, those arbitrators stand to earn substantial income in the case if it goes ahead. In some cases, ISDS arbitrators have billed for millions in arbitration fees or overseen a complex series of rulings that increased litigation costs significantly. Obviously, frivolous claims should not be vetted by someone who has a financial stake in the decision to vet. If public funds and public policy are at stake, 
there should be no connection between the profit motive of adjudicators and the outcome of cases they decide.

These flaws are unacceptable based on basic expectations of fairness and independence in adjudication. One need not go further, by inquiring into the evidence of actual systemic bias because institutional flaws alone are sufficient to undermine the claim that ISDS meets judicial standards. The situation is clearly unacceptable for making final decisions about the legal powers of sovereigns and awarding potentially massive amounts of public funds to private actors.

Even if it were shown that there are serious problems with the quality of the courts in a jurisdiction, it is not logical to replace the courts with an arbitration process that clearly gives rise to public doubts about the fairness and independence of process. ISDS worsens institutional weaknesses of domestic or regional courts by withdrawing institutional safeguards of judicial independence and fair process. ISDS is the only form of international adjudication that uses arbitration in this unique context of regulatory disputes between private parties and the state. The problems of independence and fairness follow from this ill-advised decision.

\section{The privileging of foreign investors over other actors}

ISDS gives foreign investors a range of substantive and procedural benefits that are not available to domestic investors and citizens. In doing so, it has the effect of reconfiguring state decisionmaking institutions in favour of foreign investors and to the detriment of anyone with conflicting interests. This has potentially wide-ranging implications for principles such as equal access to justice, regulatory flexibility, democratic accountability, judicial independence, market efficiency, and sanctity of contract.

For example, only foreign investors can bring an ISDS claims to protect their assets, broadly defined. The actors that typically have the most valuable foreign-owned assets, and the deepest pockets to fund litigation, are transnational corporations and individual tycoons. Through ISDS, they are given the right to bring international claims against states without a requirement to go first to the domestic or regional courts that protect everyone else's rights, regardless of whether those courts are reliable and offer justice. 
In international law, only foreign investors have been relieved of this conventional duty to exhaust local remedies when bringing a claim against the state. As such, with ISDS, it is assumed implicitly that domestic courts and legal systems in all countries systematically fail to protect foreign investors adequately. This is obviously incorrect, even if one assumed that ISDS offers a fair and independent process to replace courts in a democratic society, which it clearly does not. In the TTIP context, foreign investors have extensive protections in North American and European courts and these courts are more institutionally independent and procedurally fair than ISDS. In this context, a proposal for ISDS appears to be an indirect attack on the role of courts generally, where a foreign company objects to something that a legislature, government, or court may do.

One might also ask: what if foreign investors themselves do not respect domestic laws and the courts in a jurisdiction are inadequate to ensure they do? There are scenarios in which a domestic actor, another foreigner, or other investors would suffer greatly because of a foreign company's misconduct. Yet all of these other actors are limited to the supposed ghetto of the courts, even if the courts are shown to be corrupt or otherwise unreliable. The scenario demonstrates the gross imbalances that are inherent in ISDS.

The right to bring or threaten a parallel ISDS claim, in addition to the right to go to a domestic court (or a contractually-agreed forum) can provide major advantages to a foreign investor in its relations with the state. For example, foreign investors gain a special entitlement to public compensation and added clout in relations with governments. Indeed, ISDS favours foreign investors in a range of ways in comparison to a judicial process that would otherwise resolve disputes about the regulation of foreign investors.

For example, foreign investors can make factual claims and legal arguments in the absence of other affected parties. They are given a direct role in deciding the make-up of the tribunal. They can seek retrospective compensation for laws and regulations that they oppose; in a domestic court, such compensation is typically not the primary remedy in judicial review due to concerns about judicial encroachment on public budgets. ISDS arbitrators have overwhelmingly allowed foreign investors to challenge general laws, on a broad basis, and have almost never adopted deferential approaches used by courts to show respect for elected legislatures and expert regulatory bodies. ISDS arbitrators have also intensified conventional legal and financial 
constraints on states by interpreting the standards of foreign investor protection in investment treaties more broadly than corollary protections in domestic or customary international law.

In these respects, ISDS marks an institutional shift toward the economic interests of foreign investors and away from the interests of other actors whose representation and participation is limited to other processes. This privileging of foreign investors is discussed further in Appendix 2.

Related to this issue, the European Commission has claimed that ISDS protects the fundamental rights of foreign investors. There are two big problems with this claim. First, the Commission's approach to ISDS elevates property rights in relation to the right to regulate and other human rights. For example, there is a stark contrast between the Commission's handling of foreign investor protection and the right to regulate in the CETA and the handling of property rights and the right to regulate in the European Convention of Human Rights. Second, the Commission does not mention, let alone address, the basic contradiction between ISDS and human rights. By definition, ISDS discriminates in favour of foreign investors and against all other actors whose rights may be affected by state decisions. Unlike foreign investors, other rights-holders are limited to human rights adjudication in domestic and regional institutions.

To highlight the privileging of foreign investors, I offer this hypothetical at the extreme end of the spectrum of possible mistreatment. In the era of ISDS, if a foreign national is tortured by state officials, he or she can bring an international claim against the state - without having to resort first to domestic courts - only if he or she owns assets in the state and only to the extent that the torture affected his or her role as an asset owner. On the other hand, if a foreign investor's officials torture their domestic employees with the collaboration of the state, the employees cannot bring an international claim against the company or its officers, and can bring a claim against the state for failing to protect them only after resorting first to domestic remedies. This is an unjustified elevation of the rights of foreign investors.

\section{The risk to European standards of regulation}

ISDS poses significant risks to regulatory flexibility and democratic accountability. ISDS disciplines are unique, as the basis for litigation risk of governments, because they lead to an uncapped retrospective order of compensation against the state in its sovereign role. Thus, a 
legislative or administrative decision-maker may have to evaluate whether going ahead with a decision, over the objections of a foreign investor, will lead to uncertain but potentially costly liability. Once a law, regulation, or court decision is found to have violated the treaty, the state usually has no opportunity to avoid financial liability for the historical decision. This can create major challenges for proactive regulation and management of public funds.

In Canada, various governments have responded to ISDS in NAFTA by changing their internal decision-making to account for the risk of ISDS lawsuits. Thus, they have adopted dedicated means of review and approval to elevate the consideration of foreign investor protection in internal decision-making. In an ongoing research project I am conducting with a colleague, based on confidential interviews with several dozen officials in Canada, informants were asked if it would affect internal decision-making and possibly preclude a decision if the decision was thought to carry a non-negligible risk of potentially billion-dollar liability. The paraphrased responses have ranged from "yes it would" to "yes it would, and no one would bring forward such a proposal unless it was intended to fail".

It is also clear that a legislative, executive, or judicial decision in a developed countries, with mature courts and electoral processes, is open to challenge in ISDS, if ISDS available to foreign investors. In early debates about NAFTA, it was said that ISDS would serve to protect U.S. and Canadian investors in Mexico. Since then, ISDS has been used by U.S. investors under NAFTA about twice as often against Canada as Mexico, and Canada has been sued in ISDS more often than any developed country and more often than roughly five developing or transition countries (there is always uncertainty in these rankings due to the secrecy of some ISDS cases).

Amounts awarded against Canada to date have been significant but manageable, totaling about CAD 170 million. Yet, a wide range of measures in Canada has been attacked by U.S. investors using ISDS, as elaborated in Appendix 3, and there always remains the prospect that a single ISDS case could lead to massive liability in virtually any area of decision-making. This may in turn incent regulatory chill, either publicly or behind the scenes, when a foreign investor objects to a proposed decision.

An example of regulatory change due to ISDS is the notorious case of Ethyl $v$ Canada. In the case, the U.S. manufacturer of a gasoline additive, MMT, used an ISDS lawsuit under NAFTA successfully in its opposition to a proposed legislative ban on trade in MMT and obtained a 
settlement from the federal government that included CAD 19.5 million in compensation. The ban was prompted by automobile industry concerns that MMT interfered with new emissions control technologies in cars. MMT was also linked to uncertain health risks, causing specialist health researchers and environmental organizations to support a precautionary ban. At the time, MMT was banned or otherwise not used across nearly all the U.S., where it was manufactured.

The Ethyl lawsuit clearly contributed to the federal government's decision to withdraw its ban on MMT, give a public statement that MMT was not a health or environmental threat, and pay substantial compensation to Ethyl. Yet, ISDS proponents have claimed that the settlement, including withdrawal of the ban, was not linked to ISDS. In a 2014 study prepared for the Dutch government, for example, it was stated that the Canadian government "only agreed to settle the dispute after Canada's own provinces successfully challenged the legitimacy of the law in Canadian court", that a "dispute settlement panel invalidated the measure after finding that it exceeded the scope of the government's authority", and that "this case does not support the notion of regulatory chill because the act of regulation itself was not legal”. 3 In Appendix 4, I provide a detailed outline of Ethyl to highlight why these claims are misleading and how the ISDS lawsuit is linked to Canadians' exceptional exposure to MMT and the associated health and environmental risks during 1998 to 2004.

Incidentally, ISDS proponents have also argued, referencing the Ethyl case and similar examples, that any demonstrated regulatory changes due to ISDS were actually positive because a government's original decision was misguided. This argument shifts the debate to the merits of a decision or a change, and appears to accept that ISDS arbitrators should have the final word on the merits of all regulatory decisions that are challenged by a foreign investor in ISDS. It does not challenge the point that ISDS alters the structure and incentives of state decision-making in favour of foreign investors.

Even if a lawsuit is brought and lost by a foreign investor, or threatened but not initiated, the ability to sue in ISDS may be a unique and useful lobbying tool. To illustrate, in November of 2014, the Canadian Council of Chief Executive warned the federal government that it would face

\footnotetext{
3 C Tietje, F Baetens, and Ecorys, "The Impact of Investor-State-Dispute Settlement (ISDS) in the Transatlantic Trade and Investment Partnership", Study prepared for the Ministry of Foreign Trade and Development Cooperation and the Ministry of Foreign Affairs of the Netherlands, Doc No MINBUZA201478850 , para 169.
} 
ISDS lawsuits if it proceeded with rigorous new anti-corruption rules. ${ }^{4}$ It will be very difficult if not impossible to assess the impacts of these threats because they relate to decision-making and possible negotiations off the public record. Yet, the warnings illustrated the bargaining option that ISDS gives to major companies.

Based on the record of ISDS lawsuits against Canada, one can anticipate that a range of measures in Europe may be vulnerable to actual or threatened ISDS claims, although it is difficult to anticipate in what areas the challenges will come. Based on my own research in the area and knowledge of ISDS cases to date, I suggest that European decision-makers should be alert to the following danger zones. The list is meant to be illustrative, not exhaustive, and does not evaluate the likelihood of a threatened or actual claim for any particular decision.

- Areas in which standards in Europe are significantly more rigorous than standards in North America, such as pollution control, chemicals regulation, and privacy.

- Areas in which national or European regulations may create substantial compliance costs for foreign companies, such as in competition regulation, tax policy, and financial regulation.

- Areas of significant reform of standards, especially where they affect major infrastructure or utilities and associated services.

- Areas in which health or environmental regulations may be tightened over the objections of industry.

- Areas in which the exploitation of natural resources may create conflict for social and environmental reasons.

- Areas of economic policy that support disadvantaged regions by favouring local companies or workers.

\footnotetext{
4 B McKenna, "Ottawa could face lawsuits for strict corruption rules" Globe and Mail (24 November 2014).
} 
- Areas in which North American companies have objected to proposed standards, such as the Canadian federal government's recent campaign against distinct fuel standards for the Oil Sands.

Importantly, one should not over-state the risk of ISDS claims by all foreign investors. ISDS is most likely to be used - and credibly threatened - by major companies that have deep pockets to fund the litigation. The relatively high cost of ISDS makes it practically inaccessible for most companies and, even for large companies, an ISDS lawsuit appears usually to be a late step in the lobbying of government. Considering the financial transfers that have been ordered to date by ISDS tribunals, in all ISDS awards over US\$10 million to the spring of 2014, it is revealing that the total amount ( $\$ 6.5$ billion, including pre-award interest on raw sums) that was awarded to foreign investors was distributed roughly as follows: 5
Extra-large companies (over $\$ 10$ billion in annual revenue): $\quad 64 \%$
Large companies (over $\$ 1$ billion):
$12 \%$
Medium/ small companies (under 1 billion/ under \$100 million): $3 \%$
Individual tycoons (over $\$ 100$ million in net wealth): $\quad 16 \%$
Other natural persons (under $\$ 100$ million): $\quad 4 \%$

Incidentally, the European Commission has claimed that its model of ISDS actually preserves the right to regulate. However, the text of the Canada-EU CETA conveys a fairly clear intention to do the precisely opposite.

To preserve the right to regulate, the TTIP and the CETA would need to have a clear statement of that right in relation to the state's obligations to protect foreign investors in the investment chapter. Instead, the CETA text contains broad affirmations of the right to regulate in its (weak) chapters on labour and environmental standards, but omits such an affirmation from the investment chapter. As a result, the CETA does not affirm the right to regulate as a counter to the treaty's wide-ranging foreign investor protections and, by including the right to regulate in other CETA chapters, the text implies that the right was intentionally left out of the investment chapter. This problem is very likely to be replicated in the TTIP.

5 These figures are based on an analysis of all known investment treaty awards up to the spring of 2014. For the data and methodology see https://gusvanharten.wordpress.com. 
Worse, a rare innovation in the Commission's ISDS model appears likely to intensify the pressure on states to change their decisions in order to avoid ISDS liability. The CETA says expressly that an award may be reduced by the arbitrators if the state has removed or amended the measure that is opposed by the foreign investor. This accentuates the problem that, in the face of uncertain but potentially massive liability, a government may change a decision where it is threatened with an ISDS claim. In this respect, the Commission's approach in the CETA, and potentially in the TTIP, would intensify the pressure for regulatory chill and the corresponding threat to the right to regulate.

\section{TTIP (and to a lesser extent CETA) would expand the scope of ISDS massively}

Proponents of ISDS refer often to the figure of 3000 existing treaties that provide for some form of investor-state arbitration as a reason to support proposals for ISDS in the TTIP and the CETA. This is a dubious argument.

First, the figure of 3000 treaties is not as large as it seems. To match the legal effect of a global multilateral agreement, one would require over 19,00o bilateral treaties. The figure is also an over-estimate because some of the treaties, several hundred probably, are not in force.

Second, most existing investment treaties do not govern significant investment flows and appear unlikely ever to lead to ISDS claims. To the spring of 2010, over half of all the known ISDS cases were brought under only 17 treaties: NAFTA, the Energy Charter Treaty, and 15 bilateral investment treaties of the U.S. ${ }^{6}$

Third, as measured by the amount of FDI flows to which it would apply, the TTIP is far more significant than all of the existing investment treaties combined. For instance, the TTIP will cover approximately 50-60\% of all investment flows in and out of the U.S.7 About 15-20\% of

${ }^{6}$ This includes 61 cases under NAFTA, 24 cases under the Energy Charter Treaty, and 44 cases under U.S. BITs with Argentina, Zaire, the Czech Republic, Ecuador, Egypt, Estonia, Georgia, Jordan, Kazakhstan, Moldova, Romania, Sri Lanka, Trinidad and Tobago, Turkey, and Ukraine. The data reflects all 249 known cases with a publicly-available award (or, for NAFTA cases, a notice of intent to arbitrate) by cutoffs in the spring of 2010.

7 These approximate figures were calculated based on existing investment treaty coverage of country-bycountry inward and outward FDI flows for the U.S. in 2012 from data in Organization for Economic 
those flows are covered by existing treaties. Alongside the TTIP, a few other treaties pursued by the European Commission or the U.S. Administration - especially the Trans-Pacific Partnership (TPP), an EU-China investment treaty, and a U.S.-China investment treaty - would expand ISDS coverage to over $80 \%$ of the investment flows.

Thus, it lacks credibility to justify a major new ISDS treaty, especially in the relatively untouched domain of investment relations among developed countries, by referring to the large number of relatively-inconsequential existing treaties. With the TTIP and to a significant extent CETA (partly due to the ability of large U.S. companies to qualify as Canadian investors if they have simply a substantial business presence in Canada), the Commission and the U.S. would expand ISDS massively.

The Commission has also argued that the TTIP is needed to displace less attractive ISDS provisions in existing treaties between the U.S. and Eastern or Central European states. This assumes that the U.S. is willing to replace those treaties with ISDS in TTIP, rather than leave them to exist alongside the TTIP. It also assumes that the Commission's ISDS model is a significant improvement on the other treaties. In my view, it is not. While the Commission's model of ISDS has positive elements, ultimately it is a failure. It takes meaningful steps to address the lack of openness in ISDS and by putting modest checks on the standards of foreign investor protection. In both respects, the Commission has followed the post-2001 approach of the U.S. Indeed, the Commission's ISDS model signals most clearly that the Commission will accept almost the U.S. would request in the negotiation of ISDS in the TTIP.

Yet, neither the Commission's nor the U.S. model of ISDS addresses any of the flaws discussed in this report and, in some respects, it makes them worse. The ISDS model retains the power of for-profit arbitrators to make uncapped damages awards against the state for its legislative, governmental, and judicial conduct. It does not affirm the state's right to regulate or introduce responsibilities for foreign investors alongside their rights. It does not require foreign investors to resort to domestic courts where the courts offer justice and are clearly superior to ISDS. It exacerbates the pressure on states to self-censor in order to avoid financial liability. It gives foreign investors an unjustified special status in relation to all other actors in the marketplace

Cooperation and Development (OECD), "StatExtracts: FDI flows by partner country", available online: http://stats.oecd.org/Index.aspx?DataSetCode=FDI_FLOW_PARTNER. The figures do not account for possible forum-shopping by foreign investors which is difficult to measure, and handled in different ways by arbitrators and in existing treaties, but may expand existing coverage of ISDS. 
and in society. It does these things without any serious justification for replacing domestic and regional courts with an ISDS process that lacks basic elements of judicial independence and procedural fairness, thus tainting all outcomes in ISDS cases. 


\section{Appendix 1}

The following are two examples of how ISDS proponents have made inaccurate statements about the role of courts in North America, even in cases that proponents have pinpointed as examples of why ISDS is needed in the Canada-EU CETA or the TTIP.

In defending ISDS in the CETA, the European Commission reported inaccurately to European Parliamentarians on the Canadian administrative law case of Dunsmuir: ${ }^{8}$

"Dunsmuir $v$ New Brunswick provides that judicial review may be available despite a private clause, but that such review would be limited to 'reasonableness'.

'Reasonableness' does not allow an examination of the merits of an administrative act, but only one of process: was it transparent, reasoned, and intelligible. This limited right of action is in contrast with the protection afforded to investors in the EU...”

This description of reasonableness review based on Dunsmuir, as underlined above, was completely wrong.

Reasonableness review in Canadian law clearly allows for judicial review of the merits of administrative acts, i.e. their substantive outcomes. Indeed, that is the primary purpose of reasonableness review, as part of deference doctrine in judicial review in Canada and other countries. I am in a good position to know, having taught Dunsmuir as part of a course on Canadian administrative law since the case was decided in 2009. I also co-edit a leading textbook on Canadian administrative law. ${ }^{9}$

Briefly, in Dunsmuir, the Supreme Court of Canada applied a reasonableness standard to the review of a labour arbitrator's decision on the termination of an employee. The Supreme Court overturned this decision as unreasonable based on how the arbitrator had characterized the applicable legislation, which in turn affected procedural rights of the employee on termination

${ }^{8}$ The statement was contained in a European Commission document originally posted to this address http://www.europarl.europa.eu/sides/getAllAnswers.do? reference=E-2p013-007123\&language=EN. The statement appears to have been taken down. The inaccuracies in the statement were first highlighted by the author on November 27, 2013 in an online discussion group for specialists in ISDS.

9 For more on Dunsmuir and the role of reasonableness in Canadian judicial review, one could consult a text on Canadian administrative law, such as the one that I co-edit called Administrative Law: Cases, Text, and Materials (Emond Montgomery), especially Part III. 
of his employment. In this respect, Dunsmuir engaged procedural matters, but only after the issue on the merits was resolved. There is no question that decisions can be overturned on the merits in Canadian law pursuant to reasonableness review. A cursory review of any Canadian administrative law text will confirm this. With respect to procedural aspects of administrative acts, judicial review is based primarily on a non-deferential correctness standard with a much more limited (and somewhat contested) role for deference in the review of procedural choices by administrative bodies at a general level.

ISDS proponents have also pointed to the NAFTA case of Loewen $v$ U.S. - which involved the questionable treatment of a Canadian funerals company in Mississippi courts - as evidence of a need for ISDS to protect foreign investors in the U.S. However, they usually do not report that Loewen was lost by the Canadian investor due to an exceptionally U.S.-friendly ruling by the arbitrators. Critically, the arbitrators decided that NAFTA implicitly required the investor to exhaust all available remedies in the U.S. and that the investor failed to do so after settling the case instead of pursuing a last-chance appeal to the U.S. Supreme Court.

After Loewen was issued, a member of the NAFTA tribunal - Abner Mikva - gave a presentation at Pace Law School in which he recounted that, after agreeing to serve on the tribunal, he met with U.S. Department of Justice officials. "You know, judge," he was told by the officials, "if we lose this case we could lose NAFTA." "Well, if you want to put pressure on me," Mikva replied, "then that does it."10

Once the inaccuracies conveyed by ISDS proponents are corrected, it becomes clear that Dunsmuir and Loewen do not support the use of ISDS to address any real or perceived limitations of the courts in North America and Europe.

${ }^{10}$ Note 2 above. 


\section{Appendix 2}

A comprehensive outline of the special advantages of ISDS for foreign investors would require an extensive and detailed study of how laws and processes of ISDS compares to domestic and regional courts in all countries in North America and Europe, which is well beyond the scope of this paper. Even so, aspects of the comparison of ISDS to courts reveal the relative benefits of ISDS for transnational corporations:

- They can make their factual claims and legal arguments in the absence of all other private parties whose rights and interests are affected by the dispute.

- Unlike other affected private parties, they are given a direct and significant role in deciding the make-up of the tribunal.

- Where the foreign investor and respondent government do not agree on who should be the presiding arbitrator, as frequently happens, this person is appointed by World Bank officials. Primarily, these officials operate in a political orbit closer to the U.S. Administration than to any other government.

- All ISDS arbitrators lack the safeguards of independence that would otherwise insulate them from financial dependence on claimants, in this asymmetrical context of adjudication, and on state or private actors who have influence over case-by-case arbitrator appointments.

- Foreign investors can use ISDS to obtain retrospective public compensation for a law or regulation that they oppose. They can also seek non-monetary orders against the state in parallel domestic or regional court proceedings dealing with the same law or regulation.

In other words, they have the best of both worlds. They can pursue claims both in ISDS and in the courts (and, if available, in contractual forums). Notably, in domestic courts, money compensation is usually not the primary remedy in judicial review, due largely to concerns about potential judicial encroachment on legislative and executive control of public budgets. 
- ISDS awards are more easily enforceable, against commercial assets of the losing state or its state companies in countries around the world, than a judgment of a domestic or international court.

The explanation for this last advantage for foreign investors is complicated. The advantage arises because ISDS piggybacks on the streamlined arbitration enforcement processes of the New York Convention of 1958 and the ICSID Convention of 1965. These two conventions were originally developed for the resolution of international commercial (including contractual investor-state) disputes, not for the general protection of foreign investors from the state.

To illustrate the relative ease with which an ISDS award can be enforced, Article 54 of the ICSID Convention requires all its states parties to "recognize an [ISDS] award rendered pursuant to this Convention as binding and enforce the pecuniary obligations imposed by that award within its territories as if it were a final judgment of a court of that State". This comes without any provision for judicial review of the award in the state or in any other state or at the World Bank. Rather, ISDS awards under the ICSID Rules are subject to further review only in annulment proceedings, where a second panel of arbitrators, all chosen by the World Bank President, exercises limited oversight of the original tribunal. After this, the ICSID award becomes final and is subject to enforcement in all states parties to the Convention. No domestic or international court decision is enforceable in such a streamlined way.

There are other examples of the privileging of foreign investors in ISDS. Many become apparent only from systematic study of the arbitrators' decisions. Yet, few specialists in the field beyond trade ministries in major governments and the ISDS legal industry (some personnel go between the two) follow the awards closely. Personally, I doubt that even European Commission officials have a close grasp on what the arbitrators have decided in the record of awards to date, given the Commission's naïve reliance on textual clarifications in the CETA that do little to reign in past adventurism in the arbitrators' interpretation of the treaties.

With this in mind, a systematic study of the arbitrators' reasoning in their awards - using keyword searches of all known cases to Fall 2013 - was conducted to identify any potential situations of arbitrator restraint - similar to judicial restraint - in the review of legislatures, governments, and courts. The following summarizes the findings. ${ }^{11}$

${ }^{11}$ G Van Harten, Sovereign Choices and Sovereign Constraints (OUP, 2013). 
- ISDS arbitrators overwhelmingly allowed foreign investor lawsuits to go ahead, on a broad basis, against general laws and regulatory decisions of states.

- They almost never adopted deferential approaches that are often used by domestic and international courts to show respect for elected legislatures and expert regulatory bodies based on rationales of relative accountability or relative capacity.

- They usually avoided any explicit balancing of the foreign investor's interests against those of other actors or the public interest.

- They allowed foreign investors, on a widespread basis, to sidestep commitments on dispute settlement in a contract, even though the contract related directly to the dispute put before the treaty arbitrators.

- They intensified legal and financial constraints on states by interpreting treaty standards of foreign investor protection more broadly than the meaning of comparable standards in domestic or customary international law.

These findings gives a general sense of how the TTIP may provide further benefits for foreign investors, beyond the terms of the treaty itself, to enhance the position of transnational corporations in their dealings with legislatures, governments, and even courts.

An essential part of the arbitrators' power to favour foreign investors comes from the vagueness of investment treaties in describing foreign investor rights and protections. To an extent, this is difficult to avoid in any treaty. Yet, the vagueness in investment treaties is often wide-ranging and perilous (for the state). Overall, arbitrators have tended not to show restraint, as domestic and international courts often do in similar situations of adjudication, but instead to expand their role relative to legislatures, governments, and other adjudicative forums.

For example, the TTIP would no doubt prohibit expropriation without compensation. How far does this extend to situations of general law-making and regulation that reduce incidentally the profitability of a foreign-owned asset, but otherwise leave the asset intact? In cases of indirect expropriation, it is not always clear how much compensation should be paid and whether it 
should be reduced due to an investor's own misconduct, for example, or a legitimate public interest of the state. Also, the TTIP would also prohibit domestic investors from being treated more favourably than foreign investors. How far does this extend beyond cases of intentional discrimination to include effective or implicit discrimination?

Notoriously, the arbitrators have taken investors' right to "fair and equitable treatment" under investment treaties in a range of expansive directions. They have imported new concepts and entitlements for foreign investors to receive a stable regulatory framework, preservation of the investor's legitimate expectations, and - as mentioned earlier - one-way proportionality duties of the state in its contractual dealings with a foreign investor. These concepts are not found in the treaties; they were read in by the arbitrators. Each creates potentially serious concerns for governments when seeking to change a policy and manage public money.

A foreign investor, like anyone who owns an asset, understandingly does not want to lose out from political or regulatory changes. Yet, on what basis should ISDS arbitrators have the power to decide the degree to which an investment treaty should constrain responsible government, democratic choice, sanctity of contract, and judicial finality, for example? The arbitrators are not accountable in the manner of a legislature. They are not expert or well-positioned to balance the interests of different constituencies in the manner of a government. They are not independent and fair in the manner of a court. Why should they have the power to decide whether a foreign company should be compensated by the state, perhaps for billions of dollars, because of what a legislature, government, or court has done? 


\section{Appendix 3}

In this appendix, I include an outline of some of the decisions by Canadian legislatures, governments, or courts that have been challenged by U.S. investors using NAFTA's ISDS mechanism. This is followed by further comments on the debate over regulatory chill due to ISDS.

Examples of challenged laws:

- A proposed federal law that would prohibit trade of a gasoline additive (MMT) - which interfered with automobile emissions control systems and posed potential health risks - as an indirect way to prohibit use of the additive, apparently prompted by the limitations of federal environmental laws in Canada (Ethyl $v$ Canada, case settled on terms apparently favourable to the investor).

- A provincial law that limited the use of chemical pesticides for cosmetic purposes (Dow AgroSciences $v$ Canada, case settled on terms apparently favourable to the state).

- A provincial law that expropriated assets of a timber company - and provided for payment of compensation to be determined by a process of provincial Cabinet subject to judicial review (a privative clause in the legislation purporting to preclude judicial review has been widely misrepresented by ISDS proponents) - as the climax to a dispute over the expiry of a 100-year timber concession agreement and the company's closure of its last sawmill in the province (AbitibiBowater $v$ Canada, case settled on terms apparently favourable to the investor).

- A provincial law that put a moratorium on gas fracking in environmentally-sensitive areas in and around the Saint Lawrence Estuary and River (Lone Pine Resources $v$ Canada, case ongoing).

Examples of challenged executive or administrative acts:

- A federal government order prohibiting the export of hazardous PCB wastes to the U.S. following Canada's signature of the Basel Convention, which was to obligate Canada to 
develop domestic capacity for hazardous waste disposal and avoid trans-boundary hazardous waste shipments to non-state parties such as the U.S. (SD Myers $v$ Canada, case won by the investor).

- A provincial government order, following municipal government decisions, that terminated a controversial long-shot proposal to dispose of Toronto's waste in an abandoned northern quarry (Gallo $v$ Canada, case lost by the investor).

- Federal administrative and tax supports for Canada Post, specifically its courier services, not available to private service providers (UPS $v$ Canada, case lost by the investor).

- Federal and provincial decisions that implemented a Canada-U.S. Softwood Lumber Agreement by imposing export quotes on lumber exporters in Canada (Pope \& Talbot $v$ Canada, case won by the investor).

- A federal government order and process to phase out an agricultural pesticide (Chemtura $v$ Canada, case lost by the investor).

- A provincial government decision on the issuance of fishing licenses for outfitters (Greiner $v$ Quebec, case withdrawn by the investor and apparently settled off the public record).

- A territorial government decision that limited the availability of caribou hunting licenses (Andre $v$ Canada, case withdrawn by the investor and possibly settled off the public record).

- Federal government decisions aimed at building a new bridge to relieve congestion at a major Canada-U.S. border crossing (Detroit International Bridge $v$ Canada, case ongoing).

- Decisions on the implementation of environmental legislation that provided subsidized pricing for solar and wind power (Mesa Power $v$ Canada and Windstream Energy $v$ Canada, both cases ongoing). 


\section{Examples of challenges involving courts or tribunals:}

- Federal-provincial board decisions that tightened requirements for oil companies to spend a share of the proceeds of offshore oil exploitation on in-province research and development activities, which had been upheld in the domestic courts (Mobil Investments and Murphy Oil $v$ Canada, case won by the investor and ongoing on the issue of compensation).

- Provincial government decisions that precluded a controversial proposed quarry that was under consideration in various provincial processes including judicial review proceedings ( St Marys $v$ Canada, case settled on terms apparently favourable to the investor).

- Federal-provincial environmental assessment process that recommended non-approval of a proposed quarry expansion in an environmentally-sensitive area (Clayton/ Bilcon $v$ Canada, case ongoing).

- Federal court decisions that adopted an approach to patent law that limited the investor's eligibility for patents (Eli Lilly $v$ Canada, case ongoing).

The point of this outline is not to enter into an involved discussion of whether and why each challenge was successful and what this meant, good or ill. Rather, the point is to highlight the general range and types of measures that have been challenged by U.S. companies under NAFTA. Based on this record, one can anticipate that a wide range of measures would be vulnerable to actual or threatened ISDS lawsuits in Europe under TTIP.

As an aside, six NAFTA cases against Canada are known to have been lost by Canada, based simply on the measure of whether compensation was paid to the U.S. investor, and six NAFTA cases have not been lost following a final arbitration of the claim. About 15 apparently minor cases were withdrawn or possibly settled off the public record and nine cases are ongoing. Canada has faced a total of 35 NAFTA cases and paid out approximately $\$ 160$ million in total compensation, with a decision on the amount of compensation owed in Mobil Investments and Murphy Oil $v$ Canada awarded apparently pending.

At a general level, ISDS cases against all countries to the spring of 2010 were found to have involved challenges to legislative measures in approximately $37 \%$ of cases and executive 
measures in $98 \%$ of cases (many cases overlap). Approximately $44 \%$ of cases involved a judicial decision and $62 \%$ involved a contract, likely with its own dispute settlement provisions. On this, ISDS arbitrators have overwhelmingly not shown restraint in the face of a contractually-agreed adjudicative forum and have preferred to allow a parallel ISDS treaty claim to proceed. Finally, $50 \%$ of cases were estimated to have involved general laws, regulations, or other decisions that affected a wide range of actors beyond the foreign investor or a small group of foreign investors.

I turn next to the debate over regulatory chill. There are longstanding questions about the incidence and likelihood of regulatory change due to ISDS. Those who make the regulatory chill claim point to examples in which government decisions have been changed or compensation paid under the shadow of an actual or threatened ISDS claim. Opponents of the claim - often ISDS lawyers or arbitrators, it must be said - tend to deny that such changes were caused by ISDS or, in any event, say that the changes were positive.

It is difficult to research and give reliable answers for these questions because they raise issues about the planning and intentions of officials and institutions with respect to decisions taken largely off the public record. Reliable information on such issues ultimately requires thorough and independent investigation by an entity with proper resourcing and with state-authorized powers to compel document production and relevant testimony.

However, based on my ongoing work in an interview-based project to test expectations of regulatory chill in Canada - including about 45 interviews so far - and my knowledge of other ongoing studies, I would summarize the situation tentatively as follows, focusing on Canada's experience with ISDS under NAFTA.

a. There is evidence in multiple jurisdictions that governments have changed their internal processes and staffing to account for risks arising from ISDS. That is, they have adopted dedicated means of review and approval which elevate the consideration of foreign investor interests and protections in internal decision-making. This is especially clear at the federal government level but also in provincial governments, especially after a ministry or agency has been exposed to an actual or threatened ISDS claim.

b. ISDS disciplines clearly have contributed significantly to governments changing their decisions in some cases, in Canada and other countries. Well-documented examples are not 
widespread, presumably partly because it is difficult to get reliable public information on internal government decision-making. Based on information from confidential informants with direct knowledge of the decisions, I am aware of cases of regulatory change linked directly to ISDS that are apparently not a matter of public record.

c. There does not appear to be widespread and detailed knowledge of ISDS, including under NAFTA, among government officials in Canada. In some instances, there is a stark lack of detailed knowledge even when one may reasonably expect it to be present. For example, one official in a provincial ministry thought that ISDS disciplines prohibited only discrimination against U.S. investors, even after having had non-legal involvement in the government's response to an ISDS claim. On this basis, expectations of well-informed implementation of ISDS disciplines and self-censoring in government, whether for positive or for negative reasons, seem unrealistic.

d. Government decision-makers clearly face a learning curve on ISDS risks that appears gradual, albeit subject to sudden shocks. In particular, a government agency appears more likely to consider ISDS disciplines in internal decision-making if it has been the subject of an ISDS claim. To illustrate, one provincial ministry in Canada now has a specialized lawyer to review future decisions for compliance with ISDS disciplines since it was targeted by an ISDS lawsuit under NAFTA.

e. Due to the vagueness of the treaties and the remedial power of the arbitration mechanism, discretionary legal advice on ISDS disciplines can have significant pull on other government decision-makers and elevate the role of foreign investor protection relative to other goals and values. However, it does not always trump other concerns, especially if a regulatory proposal is supported by confident legal advice and high-level political support. For example, in some cases, a government's political commitments to health protection clearly took precedence over the legal and financial risks of ISDS.

f. ISDS disciplines are uniquely powerful because they lead to uncapped retrospective orders of monetary compensation against the state. Thus, a legislative or administrative decisionmaker may have to evaluate whether to go ahead with a decision, despite objections by a foreign investor, in a context of uncertain but potentially very costly liability. This is due to the vagueness of the treaty standards and history of conflicting ISDS decisions on key issues, 
even under a single treaty like NAFTA. The unique challenge is that, after a law, regulation, or court decision is found to have violated the treaty, the state typically has no opportunity to avoid financial liability for the historical decision. This can create major challenges for responsive regulation and management of public funds.

g. When government officials were asked whether they thought it would affect internal decision-making, and possibly preclude a proposed decision, if the decision was thought to carry a non-negligible risk of potentially billion-dollar liability in ISDS, the paraphrased responses ranged basically from "yes it would" to "yes it would, and no one would bring forward such a proposal unless it was intended to fail”.

h. Those who deny the existence of regulatory chill due to ISDS have tended to exaggerate the role played by other potential triggers of regulatory changes that are linked to ISDS, such as the portrayal of the settlement in Ethyl $v$ Canada, as being the product of domestic tribunal decision. In fact, it is quite clear that the ISDS lawsuit under NAFTA played an important and probably the leading role for the Ethyl settlement, alongside a non-binding domestic tribunal decision.

i. ISDS proponents may underplay the significance of a delay in a proposed decision, such as delays by governments in introducing anti-tobacco regulations pending resolution of the Philip Morris $v$ Australia ISDS case.

j. ISDS proponents have argued that regulatory changes clearly linked to ISDS were positive because the original decision was misguided. This argument shifts the debate to the merits of a decision and change and appears to accept that ISDS arbitrators should have the final word on the merits of any regulatory decision that is challenged by a foreign investor in ISDS.

k. ISDS is still expanding in new ways, making it even more difficult to anticipate how the system will be used in future. Foreign investors and ISDS lawyers are using ISDS in innovative ways, such as by suing Canada for federal court decisions on patent law. The arbitrators are also introducing new versions of ISDS disciplines - such as requirements for states to exercise proportionality in its contractual dealings with a foreign investor, even 
after the investor breached the relevant contract, as part of "fair and equitable treatment" and have issued progressively larger awards, now running to billions of dollars.

These points may assist in gauging the risk of ISDS claims by U.S. companies under the TTIP.

Overall, and based on a range of research on ISDS, I suggest that European decision-makers should be alert to the following areas potential danger zones for lobbying pressure and financial liability associated with ISDS. As noted earlier, the decisions that are open to challenge may be legislative, executive, or judicial although they usually involve some degree of implementation by executive actors and are clearly not limited to decisions that target a foreign investor. The list is meant to be illustrative not exhaustive and it does not seek to evaluate the likelihood of a threatened or actual ISDS claim for any particular decision.

- Areas in which standards in Europe appear to be significantly more rigorous than or otherwise different from standards in North America, such as in pollution control, chemicals regulation, and privacy protection.

- Areas in which national or European regulations may lead to substantial compliance costs for major companies, such as in competition, tax, and the financial sector.

- Areas of significant reform of national or regional standards, especially where they affect major infrastructure or utilities and the associated services.

- Areas in which health or environmental regulations may be tightened over the objections of industry.

- Areas in which conflicts over resource exploitation may arise for environmental or social reasons.

- Areas of economic policy that support disadvantaged groups or regions by favouring local companies or workers. 
- Areas in which North American companies have objected to standards in Europe, such as the Canadian federal government's campaign against proposed fuel standards affecting the Oil Sands. 


\section{Appendix 4}

An example of regulatory change due to ISDS is Ethyl $v$ Canada. This case from the late $1990 \mathrm{~s}$ was one of the first foreign investor lawsuits under any investment treaty. It was brought against Canada under NAFTA by the U.S.-based Ethyl Corporation, which manufactured a gasoline additive called MMT. In the 1990s, the Liberal federal government in Canada proposed to ban MMT in response to concerns from the automobile industry that MMT interfered with new auto pollution control technologies and in response to uncertain health risks associated with inhaling MMT in gasoline fumes.

At the time, MMT was banned or not used across nearly all the U.S. due to health and environmental concerns. Since the 1980s, Ethyl had lobbied the U.S. Environmental Protection Agency and other authorities to approve MMT in the U.S. In contrast, the federal government in Canada had approved the use of MMT in the 1980s, as a substitute for lead in gasoline, on the basis that there was insufficient evidence of health risks. In the 1990s, Ethyl mounted a public relations campaign against the federal government's proposal at the time to restrict the use of MMT.

Years before, Ethyl had lobbied against restrictions on leaded additives in gasoline, which Ethyl also manufactured, but ultimately failed. In its campaign against a ban on MMT, Ethyl and its supporters could access both NAFTA and a new internal trade deal in Canada called the Agreement on Internal Trade. These agreements gave new tools to corporate and government supporters of MMT that were not available at the time of the banning of lead in gasoline.

In the campaign against banning MMT, Ethyl was joined by oil refineries that opposed the proposed ban because it would increase their refining costs. The oil refineries lobbied provincial politicians, some of whom joined the fight against the ban. On the other hand, the automobile industry and various commentators - including specialist researchers of the potential impacts of MMT on human health - supported the ban.

Ethyl invoked the little-known ISDS mechanism in NAFTA to challenge the federal government's proposed MMT ban. The tribunal allowed Ethyl's claim to go ahead, in a decision

that apparently surprised government officials. Meanwhile, three provincial governments, led by oil-rich Alberta, brought a claim against the federal government under the Agreement on 
Internal Trade (AIT), which is largely modeled on NAFTA but applies to internal trade instead of international trade. Ethyl was not a party to the AIT dispute.

Before the NAFTA lawsuit was resolved, a majority of the AIT panel recommended that the federal government not proceed with aspects of the proposed MMT ban. In particular, the AIT tribunal's majority objected to how the federal government had pursued the ban: by limiting inter-provincial trade in MMT instead of trying to ban it under federal environmental laws.

Incidentally, the decision appeared to highlight gaps in federal environmental regulations in circumstances where a product's health or environmental risks were uncertain. One of the three AIT panel members would have dismissed Alberta's complaint, saying in dissent: ${ }^{12}$

The [federal government] has been faced with a genuine dilemma. It has received the clearest of indications from the car manufacturers that further use of MMT is incompatible with the most up to date pollution control equipment. At the same time, the [federal government] has entered into a series of agreements, both nationally and internationally, to control fuel emissions.

The evidence before us clearly showed that the Respondent spent a great deal of time and effort attempting to get a consensus between the fuel industry and the car manufacturers. This effort was not rewarded with success, and the Respondent felt that in these circumstances it had no serious alternative but to introduce legislation.

The path of a simple ban on the substance MMT was not possible, because on the evidence MMT, while noxious in large amounts, did not appear to be dangerous in small quantities. The environmental effects of MMT are cumulative and indirect, in that it appears to affect the operations of fuel control equipment in the latest model vehicles.

.... There is no doubt that the legislation is by itself an impairment of internal trade. However, it is equally clear to me that the legislation satisfies the test set out in article 404 [of the AIT]. The purpose and effect of the legislation will be to get rid of MMT as a substance in gasoline. No other substances are so named or restricted, and therefore I

\footnotetext{
${ }_{12}$ Canada, Agreement on Internal Trade, Report of the Article 1704 Panel Concerning the Dispute
} Between Alberta and Canada Regarding the Manganese-Based Fuel Additives Act (12 June 1998). 
would find that there has been "no undue impairment of access of goods", and I would also find that the measure is "not more trade restrictive than necessary to achieve the legitimate objective".

I would also disagree with my colleagues that insofar as the process followed has been less than perfect, the entire blame for this should be placed at the door of the [federal government]. This legislation was before the Parliament of Canada for over a year, and there was ample opportunity for other governments to put forward alternative measures. I note that the so-called "two pump solution" was rejected by the petroleum industry itself. We have no basis upon which to find that the differences between the parties would have been resolved if this issue had been discussed further.

In short, the Respondent took action that it concluded was necessary for air quality and the improvement of the environment. The purpose of the Agreement on Internal Trade was not to dilute the ability of responsible governments to improve the environment of Canadians, provided these measures meet the tests set out in the Agreement. I would therefore have dismissed the application.

Having lost the AIT case brought by provincial governments, the federal government announced that it was pulling the proposed ban on MMT.

It also provided a public statement that MMT did not pose a health or environmental risk and paid Ethyl Corporation approximately CAD 19.5 million in compensation for harm to its reputation. This amount was larger than the budget (CAD 16.9 million) for Environment Canada's enforcement and compliance programs at the time.

I have outlined this case at length because, like similar examples, proponents of ISDS have argued that the Ethyl settlement is not really an example of regulatory change due to ISDS. In particular, they have claimed that the settlement was caused by Alberta's AIT case, not Ethyl's ISDS lawsuit. This is typical of explanations offered by ISDS proponents in the face of clear evidence of regulatory change due to ISDS. 
For example, in a study on ISDS, prepared for the Dutch Government and submitted to the Dutch Parliament, it was stated (emphasis added):13

On the surface, the Ethyl dispute appears to be a case-in-point for regulatory chill. The Canadian government attempted to ban what it viewed as a dangerous chemical only to face a 200 million dollar suit from Ethyl, a large U.S. chemical corporation. According to some, the Canadian government's settlement with Ethyl demonstrated the government caving to corporate interests and set a dangerous precedent for future environmental regulation. The reason for the settlement, however, actually cuts against the regulatory chill argument. The Canadian government only agreed to settle the dispute after Canada's own provinces successfully challenged the legitimacy of the law in Canadian court. The dispute settlement panel invalidated the measure after finding that it exceeded the scope of the government's authority. Thus, this case does not support the notion of $\underline{\text { regulatory chill because the act of regulation itself was not legal. Ethyl's }}$ arbitration claims cannot accurately be described as threatening policy space because the government was not allowed to regulate the policy space as it did.

This summary has four key inaccuracies:

(1) it attributes the federal government's decision to settle to the AIT panel's decision alone,

(2) it claims that the AIT decision emanated from a Canadian court rather than an AIT panel,

(3) it suggests that the AIT panel issued a binding legal determination when its decision was only a recommendation,

(4) it confuses the issue of inter-provincial trade under the AIT with the issue of international trade under NAFTA, which was not the subject of the AIT decision.

${ }_{13}$ Note 3 above. 
It is more credible to say that the Ethyl settlement, given its terms and timing, was linked to both NAFTA and the AIT. The federal government's public statement and payment of compensation to Ethyl Corporation were much more clearly linked to the NAFTA lawsuit, since Ethyl was not a party to the AIT case. Even the withdrawal of the MMT ban is hard to attribute only to the AIT because the AIT panel could only make a non-binding recommendation and did not issue any recommendation on international trade of MMT.

More broadly, it is revealing that Ethyl had previously failed to keep lead in gasoline, despite uncertain scientific evidence about its consequences for human health and the environment, but Ethyl later succeeded in its opposition to the ban on MMT. A key difference was the existence of a right to use ISDS under NAFTA, supported by the AIT (which itself is largely an offspring of NAFTA). It may be said that both treaties prompted an elevation of trade values over health and environmental concerns.

In Canada, MMT was eventually phased out in 2004. On the other hand, MMT was never used widely in the U.S.; other additives replaced lead in gasoline. Thus, one can say reasonably that, for about six years (1998-2004), NAFTA contributed significantly to Canadians' exposure to MMT and associated health and environmental impacts, including indirect air pollution from automobile emissions. These are unstudied costs connected directly to, if not caused solely by, the availability of ISDS under NAFTA.

Finally, the debate over the Ethyl case reveals how ISDS proponents - including business commentators and members of the arbitration industry - have bent backwards to deflect criticism of NAFTA and ISDS. In this respect, the case indicates the general strategy of ISDS proponents:

(1) demand rigorous evidence for other side's claims that ISDS cause regulatory chill,

(2) assume that another potential factor, besides ISDS, must have caused a government to change a decision potentially linked to ISDS, and

(3) argue that any change to a government decision was in any event a good idea. 